\title{
Science tipped to score in Obama cash stimulus
}

\section{Researchers jockey for a piece of the US economic package.}

The US research community stands to gain billions of dollars in funding, as Democratic leaders in Washington DC seek to lay the foundation for a greener, more competitive economy in a \$750-billion stimulus package.

Scientific groups are actively pushing their argument that modernizing the nation's scientific infrastructure could help create the skilled workforce needed to address challenges such as global warming.

"It's amazing. The scientific community has a voice," says Maria Zuber, a geophysics professor at the Massachusetts Institute of Technology in Cambridge who testified before Nancy Pelosi, Speaker of the House of Representatives, and other Democratic leaders on 7 January. "The fact that we are invited to sit at the table with the economists when we are talking about the future of the US economy - it's like a new day."

Normally, the president proposes government spending levels in early February, and Congress adjusts and approves those over many months. The fiscal stimulus package introduced by Obama last week provides a shortcut.

The question is what kind of science and energy initiatives lawmakers will be willing to approve in a bill that is intended to provide a short-term jolt to the economy. Many Republicans are opposed to the scope of the package, and congressional Democrats have baulked at the notion of fast-tracking a bill sent down by the new administration. Pelosi said last week that she wants to see a bill by February, despite Obama's call to have it ready by his inauguration on 20 January.
Representatives from the American Physical Society began talking to Obama's transition team shortly after the November 2008 election, and have developed a shortlist of desired projects at the Department of Energy, the National Science Foundation and the National Institute of Standards and Technology. The price tag stands at nearly $\$ 3.5$ billion for dozens of projects, including renovations and upgrades at various Department of Energy labs and supercomputing work at the National Center for Atmospheric Research in Boulder, Colorado.

'Shovel-ready' projects such as these feature heavily in Obama's stimulus package, which would also include extensive tax cuts. "The only things that are in this list are approved projects" that have already gone through planning, says Michael Lubell, head of public affairs for the American Physical Society. He says the transition team warned against including anything that would constitute an ongoing funding commitment. "We are not talking about the long-term grant programmes or anything else," he says. "This is very, very short term, because those were the ground rules."

It is not clear whether calls for basic research funding, as opposed to infrastructure and technology, will make the cut. Several organizations, including the Association of American Medical Colleges and the Association of American Universities, last month asked Obama for $\$ 1.2$ billion for some 3,200 grants at the National Institutes of Health, along with an additional $\$ 1.9$-billion increase in the 2009 fiscal year.

\section{Japan greens up}

Last week, Japan's environment minister Tetsuo Saito hinted that green industrial development could play a major part in the $¥ 40$-trillion (US $\$ 445$ billion) stimulus package under discussion in parliament. He emphasized the importance of encouraging science and technology to enable Japan to recapture the world's top spot in photovoltaics and to promote wind energy, small hydroelectrics and nextgeneration cars.

As part of the stimulus, plans to expand the green industrial market from its current value of $¥ 70$ trillion to $¥ 100$ trillion, and to strengthen its workforce from 1.4 million to 2.2 million, might be brought forward from 2020 to 2015. The ministry is considering zero-interest loans for environmentally friendly companies and other measures to encourage green industry.

"Even in these harsh economic conditions, we cannot slow our efforts to deal with environmental problems," says Saito. "In fact, precisely because we have these conditions, we should make environmental protection the priming agent for explosive economic growth." David Cyranoski

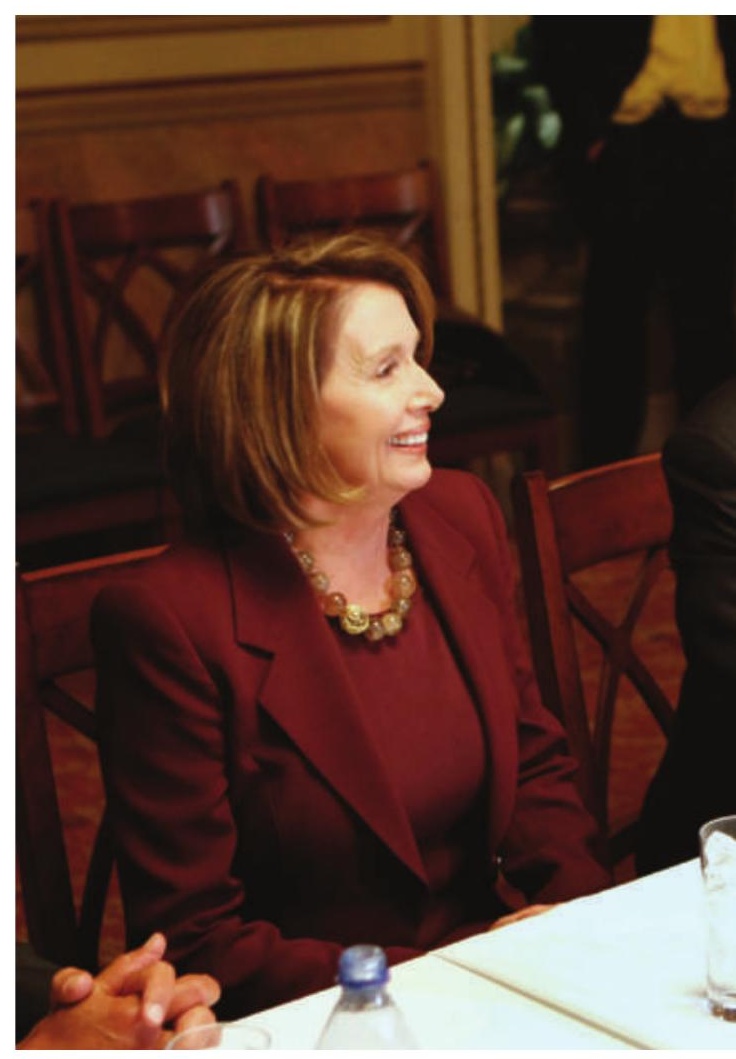

Bill Andresen, president of The Science Coalition, which represents 45 US universities, says that their goal is not a one-time boost but a rise for research funding that at least keeps up with inflation. "Whatever money is in the stimulus bill, we can spend quickly and create jobs immediately - while at the same time laying the groundwork for a more competitive economy," he says.

In their testimony last week, both Zuber and Norman Augustine, an aerospace engineer who chaired an influential National Academy of Sciences panel on US competitiveness, advocated boosting funding for the physical sciences. In 2007, Congress authorized a doubling of the physical-sciences budget under the American Competitiveness Initiative, which lawmakers have yet to fully fund. House Science Committee chairman Bart Gordon (Democrat, Tennessee) says he hopes Congress will include pieces of the initiative in the stimulus bill, although he doesn't specify which parts.

Lubell says that one area in which the incoming administration has shown a willingness for long-term projects is energy and climate, as have other countries (see 'Japan greens up'). Speaking last week at George Mason University in Fairfax, Virginia, Obama said his administration plans to double the production of renewable energy over the next three years while boosting energy efficiency in 2 million homes ( $1.6 \%$ of US housing) and in more than $75 \%$ of federal buildings. 


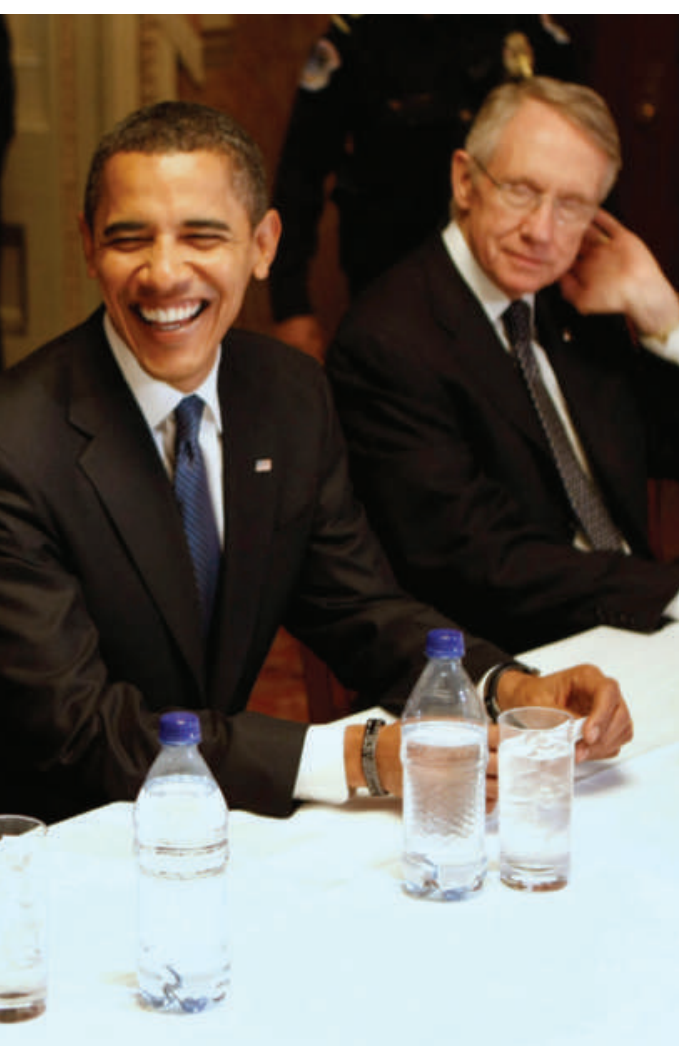

Barack Obama and Congressional Democrats brought scientists and economists to the table.

Obama has also called for modernization of the electricity grid, an initiative that could cost upwards of $\$ 165$ billion, according to the Electric Power Research Institute.

Democratic lawmakers are keen to include energy-efficiency initiatives, including weatherproofing assistance for homeowners, but questions remain about how to address renewable energy in the bill. Officials in the wind and solar energy industries say Obama's goal of doubling renewableenergy production was possible before the economic meltdown, but financing for new projects has since dried up, forcing some companies to lay off workers.

These industries are now pushing lawmakers to free up money by altering the structure of federal tax incentives that encourage the development of electricity from renewables - a move that could cost taxpayers an additional $\$ 1$ billion over the next two years. Rhone Resch, who heads the Solar Energy Industries Association in Washington DC, says the industry is ready to go to work once it can get the financing. "The policies and the programmes that worked in the past economy will not work in today's dire economic environment," he says. Jeff Tollefson

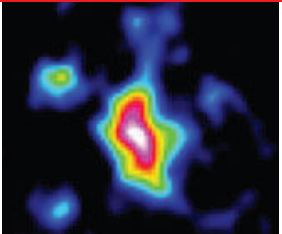

ASTRONOMY

Did black holes form before galaxies?

www.nature.com/news

\section{Steven Chu prepares for power}

On 13 January, the US Senate Committee on Energy and Natural Resources was scheduled to hold a hearing on presidentelect Barack Obama's nomination of Steven Chu for head of the Department of Energy (DoE). If confirmed as expected, Chu may well set sparks flying at the staid agency. Over the past four years, Chu has realigned the DoE's Lawrence Berkeley National Laboratory (LBNL) in California into a pioneer for alternative-energy research.

Using an ice-hockey analogy, Eddy Rubin, director both of the Joint Genome Institute in Walnut Creek, California, and of the genomics division at the LBNL, says: "You can't stay where the puck is - you have to skate where the puck is going to be. [Chu] had a compelling vision to put the lab where it needs to be."

Like many hockey greats, Chu isn't shy about asserting his position. "You say something stupid, he smacks you immediately," says one lab source who asked to remain anonymous. "I've seen him really embarrass people, to a fault."

Chu, 60, is not granting interviews until after his confirmation. But a week before Christmas, about 15 LBNL division heads and managers heard him explain how he visited Obama in Chicago around Thanksgiving, spending roughly 40 minutes alone with him. Obama was extremely knowledgeable about energy issues, Chu told the group, and their ideas for research on alternative sources were in sync.

According to the division directors, Chu said he would take the job if he could select the approximately 15 political appointees who would direct key DoE components. In the early days of the Bush administration, vice-president Dick Cheney was behind most of those appointments. Instead, "Chu will get to select the smartest people he knows", says Rubin.

Chu is deeply interested in biology, having branched far beyond the lasercooling work that won him his Nobel prize in 1997. And he is always delving into new fields, says geochemist Don DePaolo, a 20-year LBNL veteran appointed by Chu in 2007 to direct the Earth-sciences division. "In only four years at the LBNL, he learned so much about everything it is intimidating to talk to him," says DePaolo. "You can't tell him a story to patch over an issue; he zeroes in if it doesn't sound right."

But this focus has led to complaints of micromanagement. Colleagues say he "always has to be the smartest guy in the room", even privately voicing desires for a second Nobel in a biology-related field.

"He is an unabashed self-promoter," says Tad Patzek, a former researcher at the University of California, Berkeley, who clashed with Chu on bioenergy projects that Patzek considered to be 'nonsense' before moving last summer to the University of Texas at Austin. "But in fairness, he has been a very effective $L B N L$ director, enlarging the scope of energy research."

Chu has mellowed in recent years, says Stephen Quake, a biophysicist at Stanford University in California, who studied under Chu. "Everything is about the science," Quake says. "I could go into his office and tell him why I thought something he requested wouldn't work; he listened."

Three years ago at the LBNL, Chu championed an initiative called Helios to develop new research frontiers in solar power. Its flagship facilities, to be built in partnership with the University of California, Berkeley, have been delayed by environmental lawsuits and community

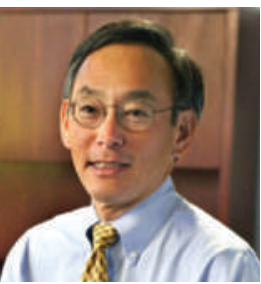

Steven Chu realigned the Lawrence Berkeley National Laboratory. objections, but are now being re-reviewed.

In 2007, Chu was also instrumental in helping the university win US\$500 million for bioenergy research from $\mathrm{BP}$, one of the world's largest energy companies - a project that triggered controversy about the role of corporate financing in academic research (see Nature 445, 688-689; 2007). That research programme has begun on the Berkeley campus, but its building is delayed along with Helios. Last year, the LBNL did successfully open its \$134-million Joint BioEnergy Institute in a gleaming facility at an industrial park in nearby Emeryville.

Chu's experience in setting up these initiatives may serve him well in Washington DC, which is full of people who think they are the smartest in the room. "He is going to take the DoE where it needs to go with new technologies," says Rubin. "He's a driver who doesn't take vacations." Rex Dalton

For coverage of Steven Chu's confirmation hearing, see http://tinyurl.com/8dgwle. 